\title{
A TUDOMÁNYOS KOMMUNIKÁCIÓS KOMPETENCIÁK INTEGRÁLÁSA A KÖNYVTÁR- ÉS INFORMÁCIÓTUDOMÁNYI TANTERVBE. ESETTANULMÁNY THAIFÖLDRÖL
}

\section{NAMTIP WIPAWIN}

\section{Tartalmi összefoglaló}

A tudományos kommunikációs kompetenciák a nyílt tudománnyal összefüggö készségek, amelyeket a tudástársadalomban be kell épiteni a formális oktatásba. A tudományos kommunikáció a könyvtári és információs hivatás egyik fontos eleme: olyan rendszer, amely segíti a kutatást és a tudományos publikálást, az információ értékelését szinvonalas terjesztése érdekében a tudományos közösség körében, és megörzését a jövö számára. E tanulmány célja a tudományos kommunikációs kompetenciák tanulmányozása a thai egyetemek könyvtár- és információtudományi tanterveiben. A minőségre irányuló kutatás módszere a dokumentumelemzés. A kutatás megállapította, hogy a legtöbb thai könyvtár- és információtudományi tanterv a következö kurzusokat tartalmazza: menedzsment, gyüjtemények, szolgáltatások és technológiai eszközök. Ahhoz, hogy a tudományos kommunikációs magkompetenciákat fejlesszék, a thai könyvtár-és információtudományi tantervekben legalább 5 tantárgynak kell módosítani mind a leírását, mind a tartalmát.

https://doi.org/10.46280/KOMPKONF.2020.Wipawin

\section{Bevezetés}

Az Association of College and Research Libraries tudományos kommunikációs kezdeményezése (2016) az oktatás és az elkötelezettség olyan megközelítését követeli meg, amely tükrözi a szakmában vállalt könyvtári és információtudományi szerepek sokféleségét. A kutatási adatok kezelésének nyitottsága következtében a könyvtárosok és információs szakemberek új szerepeket töltenek be a nyílt hozzáférés gyakorlatát követő tudomány egész életciklusa során. A tudományos kommunikációs kompetenciák olyan, a nyílt tudománnyal összefüggő készségek, amelyeket a tudástársadalomban be kell ágyazni a formális oktatás kereteibe. ${ }^{1} \mathrm{Az}$ open science olyan mozgalom, amelynek az a célja, hogy a kutatási adatok mindenki számára hozzáférhetők legyenek. A gyakorlatban olyan dolgok tartoznak ebbe a körbe, mint a nyílt

1 O'CARROL, C. et al. 2017. 
tudományos kutatás publikálása, a nyílt hozzáférési kampányok és általában a tudományos ismeretek közreadásának és kommunikációjának egyszerűbbé tétele.

A könyvtárak, kutatóközpontok és számítóközpontok együttműködése olyan kutatási adatszolgáltatásokat hoz létre, amelyek az intézmények kutatási adatok kezelésére vonatkozó politikájának eredményei. A könyvtárak új szerepe nemcsak az információk összegyüjtéséből, megszervezéséből és hozzáférhetővé tételéből áll, hanem a tudás létrehozásából és az intézmények segítéséből is a kutatási eredmények kezelésében az intézményei repozitóriumok révén. ${ }^{2}$ Ezt az új szerepet nevezzük tudományos kommunikációnak, amely egy rendszert alkot annak érdekében, hogy sor kerüljön a kutatásokra és a tudományos eredmények leírására, a következtetések színvonalas terjesztésére a tudományos közösség körében, továbbá megőrzésükre a jövőbeni felhasználás céljából. A tudományos kommunikáció a könyvtári és információs szakma alapvető ismereteinek a része. A gyűjteményfejlesztésbe beletartozik a tudományos publikálási ciklus, a gyűjteménymenedzsment, a digitális kurátorok tevékenysége, a digitális megőrzés, a gyüjteménymegőrzés és a nyilvántartások müködtetése.

A Canadian Association of Research Libraries (CARL) által összeállított, a 21. század felsőoktatási és tudományos könyvtára munkatársainak magkompetenciáit tartalmazó jegyzék hét elemet tartalmaz: alapismeretek, interperszonális készségek, irányítás és menedzsment, gyűjteményfejlesztés, információs jártasság, kutatás és a szakma fejlesztése, és információtechnológiai készségek, ezért a tudományos kommunikáció ma a könyvtári és információs szakma egyik kulcseleme, mivel egyike a felsőoktatási és tudományos könyvtárak munkatársai három magkompetenciáinak: alapismeretek, gyüjteményfejlesztés, kutatás- és szakmafejlesztés. Az új technológiák átalakítják a kutatás terjesztésének módszereit a nyílt hozzáférésü repozitóriumok révén. A tudásvagyon létrehozása az egyes intézményekben prioritást kap az egyetemek nyílt hozzáférési politikájában, a kutatási hálózatban folyó együttműködés keretében. A kihívást a hagyományos modellről - amelyben a kutatók előfizetéses folyóiratokban adják közre kutatási eredményeiket - való áttérés jelenti, és ez befolyásolja a kutatás minőségének és hatásának értékelését, mérését is. A kutatási adatok kezelésének modellje megváltoztatja annak módját is, ahogy a kutatást kommunikáljuk.

\section{Szakirodalmi szemle}

A publikációs ciklus a tudományos kommunikációt ábrázolja, amely a könyvtári és információs szakma feladata. A Felsőoktatási és Tudományos Könyvtárak Egyesülete (Association of College and Research Libraries - ACRL) szerint a tudományos kommunikáció az a rendszer, amelynek révén a kutatásokról szóló és más tudományos publikációkat elkészítik, minőségüket értékelik, terjesztik a tudományos közösség körében, és megőrzik a jövőbeli használat érdekében. A rendszerbe beletartoznak a kommunikáció formális eszközei, mint a lektorált folyóiratokban közölt cikkek és olyan információs csatornák, mint a levelezőlisták és a közösségi media. ${ }^{3}$ 


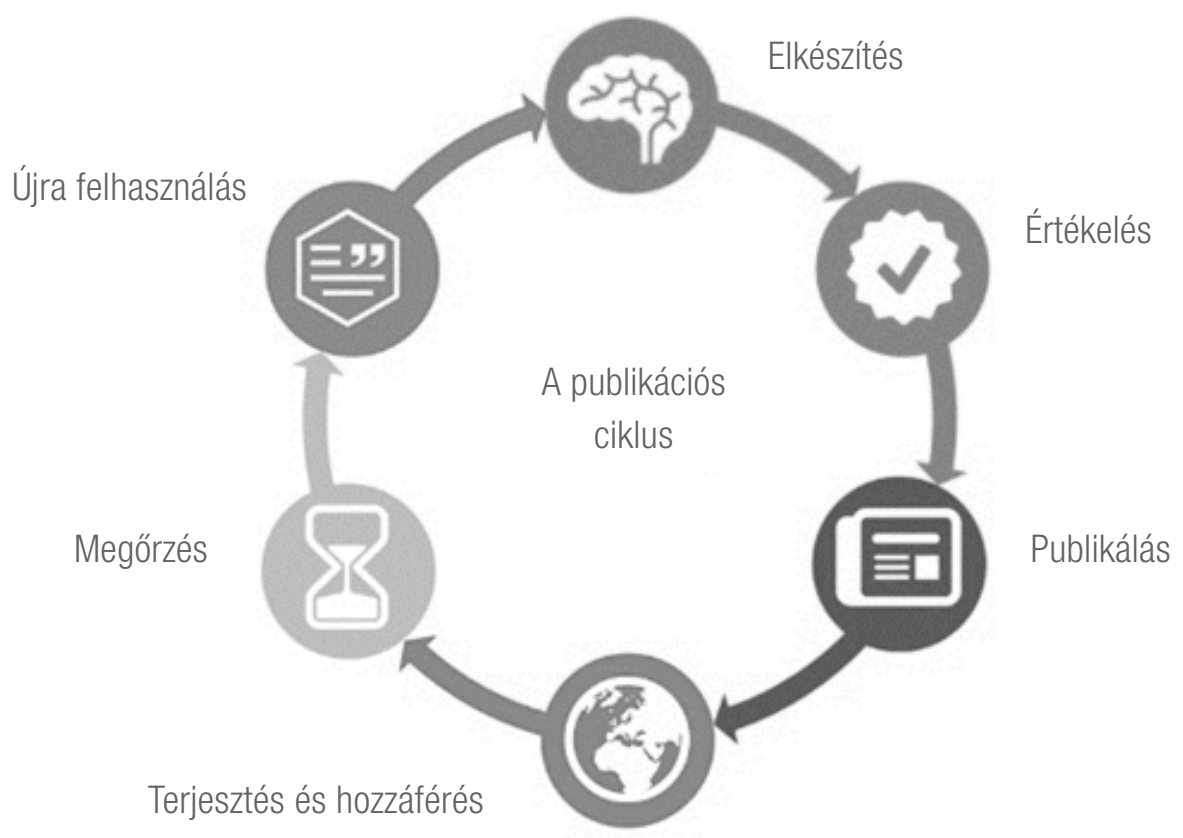

1. ábra: A publikációs ciklus ${ }^{4}$

A publikációs ciklus változó mintázata, amelybe beletartozik a kutatási adatok kezelésének új koncepciója és a nyílt hozzáférés, hat a könyvtár- és információtudományi kompetenciákra és készségekre. A tudományos kommunikációs modellek és gyakorlatok a tudás alapvetései minden könyvtáros számára. ${ }^{5}$

A NASIG (korábbi nevén a North American Serials Interest Group, Inc.), amely független intézményként azon dolgozik, hogy előre vigye és átalakítsa az információforrások kezelését, megfogalmazta és közreadta a tudományos kommunikációs könyvtárosok magkompetenciáit (Core Competencies for Scholarly Communication Librarians by the NASIG Scholarly Communication Core Competencies Task Force), melyeket a NASIG Végrehajtó Testülete 2017-ben fogadott el. A tudományos kommunikációval foglalkozó könyvtárosoknak (a továbbiakban: TKK) együtt kell dolgozniuk a feldolgozó könyvtárosokkal a metaadatok létrehozása és alkalmazása terén, a szerzői jogi könyvtárosokkal és az egyes témákkal foglalkozó kapcsolattartó könyvtárosokkal oktatási ügyekben, a kutatókkal szerzői jogi kérdésekben, a programozókkal az intézményi repozitóriummal kapcsolatban. A tudományos kommunikációs kompetenciák potenciális területei az intézményi repozitóriumok kezelése, a publikációs szolgáltatások, a szerzői jogi szolgáltatások, az adatmenedzsment-szolgáltatások, az értékelés és a hatás mérése. A részletek a következők: 


\section{Intézményi repozitóriumok menedzselése}

Az intézményi repozitórium a kutatási eredmények digitális gyűjteménye az egyes intézményen belül, amely növeli a kutatások láthatóságát és hatását, és amelyet kifejezetten arra hoztak létre, hogy e közösségek igényeit kielégítse. Russel és Day vizsgálata szerint a kutatások felhasználói fontosak a repozitórium tartalmak készítőiként és potenciális felhasználóiként is, ezért szükség van képzésre. ${ }^{6}$

1.1 Az oktatók, munkatársak és hallgatók intellektuális eredményeinek összegyüjtése, tárolása és megőrzése: az egyetem kutatási erősségeinek és a hallgatók tanulmányi eredményeinek alapos megértésére szükség van. A TKK kapcsolatokat épít ki az egész campuson, és egyezteti az intézményi repozitóriumok (IR) céljait a kutatást végzők szempontjaival.

1.2 A kutatók archiválási politikájának ismerete és alkalmazása: az IR kezelésében kritikus fontossággal bír a szerzői jog alapos megértése, különös tekintettel a kiadók archiválási politikájára. A TKK-nak alaposan értenie kell a szerzői jogot általában, a szerzői jog átadásáról szóló megállapodásokat, és képesnek kell lennie arra, hogy kifejtse ezen megállapodásokat a kutatók előtt.

1.3 A metaadat-sémák alkalmazásának ismerete és képessége: a TKK-nak, gyakran a feldolgozásban dolgozó szakemberekkel és a kutatási partnerekkel együttmüködve, értenie és alkalmaznia kell a megfelelő metaadat-sémákat. Ez a szerep egyre fontosabb, mivel a meglévő repozitóriumok között új interoperabilitási eszközök jelennek meg. Hogy a metaadatok létrehozása és alkalmazása mennyire a TKK feladata, az attól függ, milyen ismeretekkel rendelkeznek a feldolgozó könyvtárosok.

1.4 A repozitóriumi megoldások ismerete és ezekkel szerzett tapasztalatok: szükség van a különböző (szolgáltatott és nyílt forráskódú) nyilt hozzáférésű repozitóriumok megoldásainak ismeretére. Hogy egy bizonyos repozitóriumi megoldást milyen mélységben értünk meg, az attól függ, milyen megoldást alkalmaznak a TKK intézményében, és milyen mértékben felelős a könyvtáros a müködtetésért, s a programozó munkatársak milyen mértékben állnak rendelkezésre a repozitórium támogatásához.

1.5 Eljárások kialakitásának képessége: együttműködve más könyvtárosokkal, a campus kutatóival, az általános tanáccsal és a képzőintézménnyel (az elektronikus szakdolgozatok és disszertációk esetében) a TKK hozzájárulhat a nyilt hozzáféréssel, a gyüjteményfejlesztéssel, a digitális megőrzéssel, a szerzői joggal és a szerzői jog alá tartozó szolgáltatásokkal és a kiadói embargókkal kapcsolatos politikák kialakításához és megvalósításához.

1.6 Statisztikai jelentés készitése a nyilvános szolgáltatások és az oktatás támogatására: a repozitórium használati adatai felhasználhatók a nyilvános szolgáltatásokban, az oktatásban és a népszerűsítésben. Hogy a TKK mennyire felelös a statisztikák elöállításáért, attól függ, hogy mennyire széles körűek feladatai a repozitórium működtetésében.

6 RUSSELL, R. - DAY, M. (2010): Institutional repository interaction with research users. A review of current practice. New Review of Academic Librarianship Forrás: https://www.tandfonline.com/doi/ abs/10.1080/13614533.2010.509996 [2018. október 31.] 


\section{Publikálási szolgáltatások}

A publikálási (kiadói) szolgáltatások dolgozhatnak folyóiratokkal, monográfiákkal, konferencia-előadásokkal, nyílt oktatási anyagokkal (OER) vagy digitális (humán) tudományi projektekkel. E szolgáltatások megvalósulhatnak a könyvtár révén, együttmüködve az egyetemi kiadóval.

2.1 A publikációs platformok ismerete és ezekkel szerzett tapasztalatok: a TKK-nak ismernie kell/tapasztalatokkal kell rendelkeznie mind a nyílt forráskódú, mind a szolgáltatott kiadói megoldások és e-publikálási eszközök terén.

2.2 A kiadás teljes életciklusának ismerete és az ezekkel szerzett tapasztalatok: a TKK segíti a kutatók munkáját a kiadói folyamat bármely szakaszában, a szerkesztési munkafolyamatoktól a digitális megőrzésig és elérhetőségig. A TKK-t megkérhetik arra, hogy vegyen részt a kiadói partnerekkel kötött együttmüködési megállapodások kidolgozásában és értékelésében. A TKK-nak képesnek kell lennie, hogy megtervezze és koordinálja az archivált tartalom beadását és migrálását, amihez számítógépes készség (Excel és/vagy XML) is szükséges lehet.

2.3 A különböző azonosítók ismerete és ezekkel szerzett tapasztalatok: személyes vagy intézményi szintü CrossRef vagy Datacite DOI-k, Handles, ORCiD, ISSN-ek.

2.4 A szóba jöhető metaadat-sémák alapjainak ismerete: a TKK koordinálhatja a metaadatok letétbe helyezését a CrossRefnél, az EZID-nál, a Directory of open access Journalsnál (DOAJ) és a folyóirat-aggregátoroknál, ezért értenie kell ezekhez a sémákhoz, például a Dublin Core-hoz.

2.5 Technikai segítségnyújtás: a szolgáltatási szintek különbözőek lehetnek attól függően, hogy nyílt forráskódú vagy szolgáltatott platformról van-e szó. A TTK gondoskodik a publikációk létrehozásáról, a folyamatos hibaelhárításról, vagy együttműködik a szolgáltatás támogatási hátterével. Szolgáltatott megoldás esetén gyakran a teljes technikai támogatás rendelkezésére áll, de előfordulhat, hogy neki kell tartalmat hozzáadnia és a szerkesztők weboldalait gondoznia.

2.6 Rendszergazdai teendők és programozás: a TKK, aki nyílt forráskódú rendszert használ, felügyelheti a rendszeroldali menedzsmentet és a programozást is, valamint elláthatja a front-end rendszergazda szerepét, míg mások az előbbihez információtechnikai támogatást kaphatnak.

2.7 Értékelési módszerek összegyüjtése és terjesztése: a TKK más munkatársakkal együttmüködve alakíthat ki értékelési és mérési módszereket a hatékonyság és a szolgáltatások hatásának méréséhez. 


\section{Szerzői jogi szolgáltatások}

A szerzői jogi szolgáltatások intézményenként mások és mások. Minden TKK-nak általánosságban véve értenie kell a szerzői jogi jogszabályokhoz és a kapcsolódó megállapodásokhoz, a jogi környezethez.

3.1 Az érvényes nemzeti szerzöi jogi rendelkezések ismerete: Az amerikai szerzői jog esetében a TKK-knak ismerniük kell a következőket:

- a kizárólagos jogot és időtartamát,

- a mentességeket és alkalmazásukat, köztük a következőket:

- méltányos használat,

- oktatási mentességek (az amerikai jogon belül az osztálytermi mentesség és a TEACH-törvény),

- könyvtári mentességek (kutatási és megőrzési célú másolás esetén),

- nyilvános domén, ahol a dokumentumok szerzői joga már lejárt vagy meghatározott célt szolgál; a TKK-knak el kell tudniuk magyarázni, mit jelent ez egy adott dokumentum használatánál, és segítenie a kutatónak, hogy meghatározza, a nyilvános doménbe tartozik-e vagy sem,

- nemzetközi megállapodások hatása, beleértve a szerzői jogi védettség eltérő időtartamát.

3.2 A bírósági környezet naprakész ismerete: a TKK-nak nyomon kell követnie a jelentős szerzői jogi eseteket, és meg kell fontolnia az esetek lehetséges hatásait a helyi gyakorlatra (pl. a Google Books, a HathiTrust vagy a Georgia State University esetét).

3.3 A szerző jogainak megértése: a TKK-nak meg kell értenie a szerzőket jogtulajdonosként megillető jogokat, a részletkérdéseket is beleértve, és bátorítaniuk kell őket, hogy a kiadókkal szemben lépjenek fel annak érdekében, hogy kívánságaik szerint érvényesüljenek jogaik. Emellett a TKK-nak jól kell ismernie a kiadási megállapodásokat és a szerződések függelékeit, és felkészültnek kell lennie ahhoz, hogy ezeket a szerzőnek elmagyarázza. A TKK-nak értenie kell a Creative Commons licencekhez és azok alkalmazásához.

3.4 Az árva müvek ismerete: a TKK-nak tudnia kell, hogy léteznek árva művek, és ismernie kell a jó gyakorlatokat, amikor az engedélyezés módját vagy az érveket keresi a méltányos használathoz vagy digitalizáláshoz.

3.5 Licencelési szolgáltatások teljesitése: néhány intézményben a TKK-tól elvárják, hogy segítsen értelmezni vagy megfogalmazni a dokumentumok használati licenceit. A TKK-t felkérhetik, hogy állapítsa meg, létezik-e licenc valamely szerzői jogi védettség alá tartozó dokumentumra egyetemi előfizetés vagy a használattal arányos térítés ellenében közös jogkezelőnél vagy társulásnál.

3.6 Engedélykérés kezelése: a TKK-nak fel kell ismernie az engedélykérés szükséges elemeit olyan használatok esetében, amelyek nem minősülnek méltányosnak. Néhány intézménynél a TKK segíthet megfogalmazni vagy kiküldeni az engedélykérést, vagy rendelkezésre bocsáthat formaleveleket az engedélykéréshez. 
3.7 Egész campusra kiterjedő szerzői jogi eljárások: a TKK-nak ismernie kell az egész campusra kiterjedő szerzői jogi eljárásokat. Felkérhetik, hogy nyújtson iránymutatást a campus szerzői által előállított művek használatának és tulajdonjogának megértését illetően, és arra, hogy készítse el az egyetem szerzői jogi eljárásainak a szabályzatát. Emellett - amennyiben szerzői jogi tanácsadást és szolgáltatást is végez - készíthet eljárásokat és szabályzatokat a szerzői jogi azolgáltatásokhoz.

\section{Adatmenedzsment-szolgáltatások}

$\mathrm{Az}$ adatmenedzsment-szolgáltatások növelik minden felsőoktatásban müködő könyvtáros szerepének a fontosságát, mivel olyan feladatokat rónak rájuk, melyek a tudományos nyilvántartások természetében bekövetkezett változásokkal függnek össze. Matusiak és Sposito tanulmánya szerint a kutatási adatok menedzselésével kapcsolatos szolgáltatások elsősorban a felsőoktatási könyvtárakban lelhetők fel a kutatási és konzultációs szolgáltatások vagy a digitális tudományos részlegek keretében.?

4.1 Adatok leírása és tárolása: a TKK együttműködik a kutatókkal, a feldolgozó könyvtárosokkal és a számítógépes szakemberekkel annak érdekében, hogy metaadat-sémákat fejlesszenek ki a kutatók által generált adatfájlokhoz és együttmüködjenek technikai megoldások fejlesztésében az adatfájlok megőrzése és megosztása érdekében.

4.2 Adatmenedzsment tervezése: a TKK együttműködik az intézményi kutatási irodákkal és a tanszéki kutatókkal, tanácsot ad a pályázatok adatmenedzsment-tervezéssel kapcsolatos részéhez. Ebbe beletartozik az oktatás és az eszközök ismerete, ilyen például a University of California DMPTool eszköze (amely az adatmenedzsment tervezésére való) és az RDMRose.

4.3 A támogatói megbizások ismerete és ezek alkalmazása az adatok tárolásával, hozzáférhetövé tételével és megörzésével kapcsolatban: az adatmenedzsment területe gyorsan fejlődik. Ennek a kompetenciának a teljesítése aktív részvételt kíván a szakmában és törvényhozói környezetben, miközben belső teamek építésére van szükség a campus közösségének oktatása és a felmerülő kutatási adatmenedzsmenttel kapcsolatos igények kielégítésére.

4.4 Nyilt forráskódú és szolgáltatott adatrepozitóriumok megoldásainak ismerete és azzal szerzett tapasztalatok: az adatrepozitóriumokkal kapcsolatos megoldások széles körü ismeretére van szükség, és ennek a tudásnak a mélységét a meglévő intézeti infrastruktúra határozza meg. A TKK-nak tisztában kell lennie a jelenlegi intézményi repozitóriumok képességeivel az adatmenedzsment támogatása (pl. DSpace, Digital Commons, Fedora), valamint az általános adatspecifikus repozitóriumok területén (pl. Figshare, Dryad), és meg kell tudnia határozni a megfelelő tematikus adatrepozitóriumokat.

7 MATUSIAK, K. K. - SPOSITO, F. A. (2017): Types of research data management services. An international perspective. Forrás: https://onlinelibrary.wiley.com/doi/full/10.1002/pra2.2017.14505401144 [2018. október 31.] 
4.5 Harmadik fél adatfájljainak gyüjteményfejlesztése, szervezése és hozzáférése: a TKK campusán előállított kutatási adatok kezelésén túlmenően a TKK-t be lehet vonni harmadik fél adatfájljainak beszerzésébe, megszervezésébe, ahhoz hozzáférés biztosításába a kutatási és oktatási felhasználás érdekében.

\section{Az értékelés és hatás mérőszámai}

A könyvtárosok segítenek a szerzőknek, hogy meghatározzák tudományos tevékenységük hatását, mégpedig a hivatkozások megszámlásával és a folyóiratok impakt faktorának közreadásával. E mérések közé olyan alternatív módszerek, hatásmérések tartoznak, melyek kiszámíthatók a cikkek, könyvek, adatfájlok, prezentációk, forráskódok és egyéb kutatási eredmények esetében.

5.1 A kutatások hatását jelzö indikátorok, azok erősségeinek és korlátainak megértése: a TKK-knak ismerniük kell a kutatásértékelési módszerek és hatásmérési eszközök széles körét, például a bibliometriát és az altmetriát, valamint a minőségi méréseket, mint amilyen a szakértői lektorálás. Emellett a kutatást a kutatási eredmények négy szintjével lehet értékelni: az egyéni tudományos teljesítménnyel, mint a folyóiratcikkek; a tudományos kutatási fórumokkal, ilyenek a folyóiratok; a szerző teljesítményével egy hosszabb időszak alatt, és a csoportos vagy intézményi teljesítménnyel. ${ }^{8}$ A TKK-knak fel kell ismerniük a kutatás hatásával kapcsolatos különböző indikátorokat, és azt, hogy egyetlen indikátor vagy mérés sem jelzi automatikusan a minőséget. A TKK-knak figyelemmel kell kísérniük a kutatási hatásmérések változó környezetét és téves alkalmazásuk kritikáit, mint pl. amikor a folyóirat impakt faktorát (Journal Impact Factor, JIF) csak arra használják, hogy egy bizonyos szerző karrierbeli előrelépését vagy pályázati támogatásának elnyerését igazolják.

5.2 A hatás mérésére szolgáló alternatív módszerek megértése: a TKK-knak ismerniük kell az egyéni és intézményi szintü, a cikk szintű (pl. SNIP), a folyóirat szintű (pl. Eigenfactor), h-indexet alkalmazó (folyóirat szintű vagy szerzői szintü) altmetriát, illetve a prezentálásukhoz szükséges eszközöket (pl. Plum, Altmetric.com, PLOS).

5.3 Az oktatók profilrendszerének és a felsőoktatási közösségi hálózatoknak ismerete: sok intézmény hozott létre oktatói profilrendszert, ilyen a VIVO vagy a PURE, hogy hangsúlyozzák oktatóik termékeny munkásságát, és lehetőséget teremtsenek számukra az együttműködésre. A tanszéki szerzők gyorsan elfogadták a különböző felsőoktatási közösségi hálózatokat, amilyen a ResearchGate, az Academia.edu és a Mendeley, amelyekkel létrehozhatnak egyéni profilokat, felsorolhatják eredményeiket, és megoszthatják cikkeik különböző változatait. A TKK kiegyenlítő szerepet tölt be, és segíthet a szerzőknek a publikációk felsorolásában, és a cikkek megfelelő változatainak a megosztásában e rendszerek révén. 
5.4 Az oktatók tevékenységével kapcsolatos jelentő rendszer tevékenységének ismerete: számos föiskola és egyetem megköveteli, hogy oktatói regisztrálják oktatási, kutatási és tudományos tevékenységüket különböző rendszerekben (pl. Digital Measures, Sedona, Elements, Data180). A TKK ismeri a publikálási környezetet, és ez olyan tapasztalat, amely hasznos lehet az oktatók számára is. E rendszerek némelyike közvetlen elhelyezést tesz lehetővé az intézményi repozitóriumokban, mások tartalmazzák a hivatkozásokat és az altmetriai értékeket. A TKK segíthet abban, hogy megvalósítsák és igazolják az elhelyezés tényét, és értelmezzék a hatással kapcsolatos értékeket.

5.5 A folyóiratok értékelése (nyillt hozzáférésü és hagyományos): a témafelelös kapcsolattartókkal és a tanszéki oktatókkal együttmüködve a TKK értékeli a folyóiratok hatását és publikálási szigorát, vagy segít az oktatóknak kutatásaik új közlési csatornákat kideríteni. A TKK az illetékes bizottságok kérésére információt adhat a mérésekről az oktatók státuszának alátámasztása és előléptetésük érdekében.

\section{Tudományos kommunikációs kompetenciák a thai egyetemek könyvtár- és információtudományi tanterveiben}

Célok: a cél a tudományos kommunikációs kompetenciák tanulmányozása a thai egyetemek könyvtár- és információtudományi tanterveiben.

Módszerek: a minőségre irányuló kutatás módszere a dokumentumelemzés; forrásként a tudományos kommunikációs könyvtárosok számára megfogalmazott NASIGmagkompetenciák, valamint két thai könyvtár- és információtudományi tanterv (Saun Dusit University és Sukhothai Thammathirat Open University) kurzusleírásai szolgáltak.

Megállapitások: az alapképzési programnak az a küldetése, hogy olyan könyvtári és információs szakembereket képezzen, akik a könyvtári és információs szakterületen fognak elhelyezkedni, a kormányzati vagy a magánszektorban. Thaiföldön tizenöt egyetem és húsz, a Rajabhat Egyetemhez tartozó könyvtárosképző iskola szervez bachelor szintű információtudományi, könyvtár- és információtudományi, információtudományi és információs menedzsment kurzust.

A vizsgálat megállapította, hogy a legtöbb thai könyvtár- és információtudományi tanterv menedzsmenttel, gyüjteményszervezéssel, szolgáltatásokkal és technológiai eszközökkel foglalkozó kurzusokból áll. Az információs repozitóriumok kezelésének témája a technológiai eszközökkel foglalkozó három tárgyban is szerepel: az információvisszakeresésben, könyvtári adatbázisokban és az információs tartalmak létrehozásában.

A szerzői jogi szolgáltatások kérdései a menedzsment-kurzusok tematikájába kerültek. 


\begin{tabular}{|c|c|}
\hline Kötelező kurzusok (59 kredit) & Választható kurzusok (30 kredit) \\
\hline $\begin{array}{l}\text { Menedzsment } \\
\text { Információ, könyvtár és társadalom } \\
\text { Könyvtár- és információmenedzsment } \\
\text { Gyüjteményfejlesztés } \\
\text { Információforrások gyarapítása } \\
\text { Információforrások katalogizálása } \\
\text { Információforrások osztályozása } \\
\text { Tudásrendszerek szervezése } \\
\text { Szolgáltatások } \\
\text { Információszolgáltatás és -terjesztés } \\
\text { Tájékoztató és információs szolgáltatás } \\
\text { Felhasználói vizsgálatok } \\
\text { Olvasás és élethosszig tartó tanulás } \\
\text { Kommunikáció az információs munkában } \\
\text { Technológiai eszközök } \\
\text { Információvisszakeresés } \\
\text { Könyvtári adatbázis-menedzsement } \\
\text { Információs tartalom létrehozása }\end{array}$ & $\begin{array}{l}\text { Menedzsment } \\
\text { Információmenedzsment gyermekek számára } \\
\text { Információmenedzsment fiatalok, idősek, hátrányokkal élők } \\
\text { számára } \\
\text { A helyi bölcsesség menedzsmentje } \\
\text { Gyüjteményfejlesztés } \\
\text { Elektronikus kiadványok } \\
\text { A Library of Congress osztályozási rendszere } \\
\text { Információforrások és szolgáltatások a természet-, bölcsész- és } \\
\text { társadalom-tudományok területén } \\
\text { Technológiai eszközök } \\
\text { Programozás a könyvtári munkában } \\
\text { Rendszerelemzés és -tervezés } \\
\text { Szoftverek alkalmazása a könyvtári, információs munkában } \\
\text { Könyvtári és információs webfejlesztés } \\
\text { Webes adatbázisfejlesztés } \\
\text { Közösségi hálózatépités a könyvtárban }\end{array}$ \\
\hline
\end{tabular}

1. táblázat: Kötelezó és választható kurzusok

\subsection{A tudományos kommunikációs kompetenciák integrálása a thai könyvtár-és információtudományi tantervbe}

A tárgyak leírását legalább öt tárgy esetében felül kell vizsgálni a tudományos kommunikáció alapvető kompetenciáinak növelése érdekében.

\begin{tabular}{|c|c|}
\hline Thai könyvtár- és információtudományi tanterv & Tudományos kommunikációs kompetenciák \\
\hline $\begin{array}{l}\text { Menedzsment } \\
\text { (1) Információ, könyvtár és társadalom } \\
\text { Az információ, könyvtár és társadalom szerepe és } \\
\text { fontossága; a könyvtár fejlődése; az információ, } \\
\text { könyvtár és társadalom kapcsolata; az információval és } \\
\text { a könyvtárral kapcsolatos koncepciók; a könyvtár- és } \\
\text { információtudomány oktatása és a munkatársak } \\
\text { (2) Könyvtárak és információs szervezetek } \\
\text { menedzsmentje } \\
\text { A könyvtárak és információs szervezetek } \\
\text { menedzsmentjének koncepciója és alapelvei; tervezés; } \\
\text { emberi erőforrások menedzsmentje, költségvetési } \\
\text { menedzsment; kommunikációs menedzsment; } \\
\text { változásmenedzsment; kockázatmenedzsment; technológia- } \\
\text { menedzsment; irányítás és motiválás; könyvtári és } \\
\text { információs szervezetek normatívái és minőségbiztositása }\end{array}$ & $\begin{array}{l}\text { Menedzsment } \\
\text { Kiadói szolgáltatások } \\
\text { A publikációs platformok ismerete és gyakorlata, a publikálás teljes } \\
\text { életciklusa, azonosítók generálása, metaadat-sémák, Technikai } \\
\text { támogatás nyújtása, Rendszergazdai teendők és programozás, } \\
\text { Értékelési módszerek összegyűjtése és terjesztése } \\
\text { Szerzői jogi szolgáltatások } \\
\text { - A nemzeti szerzői jogi szabályozás ismerete } \\
\text { - A szerző jogainak értése } \\
\text { Értékelés és hatásmérés } \\
\text { - A kutatási impakt faktorok megértése } \\
\text { - A hatásmérés felmerülő alternatíváinak megértése } \\
\text { - Az oktatói profilrendszerek és a felsőoktatási közösségi hálózatok } \\
\text { ismerete } \\
\text { - Az oktatók tevékenységéről szóló beszámolási rendszer ismerete } \\
\text { - Folyóiratok értékelése } \\
\text { CARL-kompetenciák: } \\
\text { - Irányítás és menedzsment } \\
\text { - Interperszonális készségek } \\
\text { - Kutatás és publikálás } \\
\text { - Szakmai egyesületek }\end{array}$ \\
\hline
\end{tabular}


Thai könyvtár- és információtudományi tanterv

\section{Gyüjtemény}

(3) Információforrások gyarapításat

Az információs források gyarapításának koncepciói és alapelvei; az információforrások típusai és jellemzői; információforrások;

az információforrások gyarapításának folyamatai; együttműködés és hálózat az információforrások gyarapításában; a technológia felhasználása az információforrások gyarapításában

\section{Szolgáltatások}

\section{(4)Információszolgáltatás és -terjesztés}

A könyvtári szolgáltatások és az információterjesztés koncepciói és alapelvei; a könyvtári szolgáltatások és az információterjesztés tervezése és menedzsmentje; az információk újracsomagolása; a technológia felhasználása a könyvtári szolgáltatásokban és az információterjesztésben; a könyvtári szolgáltatások és az információterjesztés minősége; a könyvtári szolgáltatások és az információterjesztés értékelése; a könyvtári szolgáltatások és az információterjesztés jogi és etikai kérdései

\section{Tudományos kommunikációs kompetenciák}

\section{Gyüjtemény}

\section{CARL kompetenciák:}

A tudományos publikálás ciklusa

Gyüjteményfejlesztés

Metaadatok és tartós azonosítók

Digitális kurátori teendők

Digitális megőrzés

Nyilvántartások menedzsmentje

\section{Szolgáltatások}

Adatmenedzsment szolgáltatások

- Adatok leirása és tárolása

- Adatmenedzsment tervezése

- Az adattárolással, hozzáféréssel és megőrzéssel kapcsolatos támogatói megbízások ismerete és alkalmazása

- A nyilt hozzáféréssel és a tárolt adatok repozitóriumával kapcsolatos megoldások ismerete és gyakorlata.

- Állománygyarapítás, harmadik fél adatfájljának szervezése és elérése

CARL kompetenciák:

Tájékoztató szolgálat

Felhasználók iránti elkötelezettség

Információs és adatjártasság

Kritikus gondolkodás és élethosszig tartó tanulás

A felhasználóképzés módszertana

\section{Technológiai eszközök}

\section{(5)Információvisszakeresés}

Adatbázisok típusai és struktúrái;

az információvisszakeresés koncepciói és alapelvei;

információvisszakereső rendszerek;

az információvisszakereső rendszerek értékelése; információvisszakereső eszközök;

az információvisszakeresés technikái és stratégiái

\section{Technológiai eszközök}

Intézményi repozitóriumok menedzsmentje

- Oktatók, munkatársak és hallgatók szellemi termékeinek gyűjitése, tárolása és megőrzése

- Kiadói szabályok ismerete és alkalmazásának képessége az archiválásban

- Metaadat-sémák ismerete és alkalmazási képessége

- Repozitóriumok kialakításának ismerete és gyakorlata

- Szabályzatok készítésének képessége

- Statisztikakészítés a külső támogatók és az oktatás segítésére

\section{CARL kompetenciák:}

Integrált könyvtári rendszer

Adatbázis menedzsment

Intézményi repozitóriumok

Elektronikus kutatásmenedzsment

Weblap fejlesztés

Új web-technológiák (online hálózati eszközök)

Tanulásmenedzsment rendszer (LMS)

\section{2. táblázat: A thai könyvtár-és információtudományi tanterv és a tudományos kommunikációs} kompetenciák

A thai könyvtár- és információtudományi tantervnek a tudományos kommunikációs kompetenciákat oly módon kell beillesztenie a menedzsment- és a gyüjteményszervezési kurzusokba, hogy a publikálással és a szerzői joggal kapcsolatos szolgáltatások is bekerüljenek a kurzus leírásába. Az információs technológia kurzus kiegészül az intézményi repozitóriumok menedzsmentjének és az adatmenedzsmentnek a kurzusleírásával, az információs szolgáltatások kurzus pedig az értékeléssel és a hatás mérésével. 


\section{Összefoglalás}

A tudományos kommunikációs kompetenciák a nyílt tudománnyal összefüggő készségek, melyeket a tudástársadalomban be kell építeni a formális oktatásba. Ezért a thai könyvtár- és információtudományi tantervet a tudományos kommunikációs rendszer változásaival összhangban módosítani szükséges. Ez a rendszer segíti a kutatást és a tudományos publikálást, az információ értékelését színvonalas terjesztése érdekében a tudományos közösség körében és megőrzését a jövő számára. A könyvtár- és információtudományi oktatók és a könyvtárosok a tantervek fejlesztésével kapcsolatban az információs szakembereknek azokról a kompetenciáiról folytatnak megbeszéléseket, amelyek ahhoz szükségesek, hogy a könyvtárakban, levéltárakban, múzeumokban és hasonló intézményekben a digitális korszakban hatékony és eredményes szakemberekként müködjenek. ${ }^{9}$

A legtöbb thai tanterv a következő kurzusokat tartalmazza: menedzsment, gyüjtemény, szolgáltatások és technológiai eszközök. Ahhoz, hogy a thai könyvtár- és információtudományi tantervben előmozdítsuk az magkompetenciákat, legalább öt tantárgy kurzusleírását módosítani kell. Saladyanant írása összeveti a thai egyetemeken kínált kilenc könyvtár- és információtudományi kurzus mester fokozatú programjának tanterveiben szereplő kurzusokat az IFLA irányelveinek (Guidelines for Professional Library/Information Programs) G2 elemével, a tanterv elemeivel. ${ }^{10}$ Azt találták, hogy 43 kurzus van, amely az IKT alkalmazásával foglalkozik a könyvtári és információs termékekben és szolgáltatásokban; 28 kurzus szól az információs források menedzsmentjéről, és 12 kurzus az információigények értékeléséről, továbbá az ezekre válaszoló szolgáltatások megtervezéséről. Csak egy kurzus szerepel a tájékoztatás eredményeinek értékeléséről, és két kurzus a helyi erőforrásokról. A thaiföldi felsőoktatás egésze követi az Oktatási Minisztérium Felsőoktatási Hivatalának az alapképzésre és a posztgraduális képzésre vonatkozó normatív kritériumait. A könyvtár- és információtudományi programok összhangban vannak a korábbi Egyetemügyi Minisztériumnak a felsőoktatási könyvtárakról szóló normatíváival is.

A könyvtár- és információtudományi tantervben a tudományos kommunikációs kompetenciák fejlesztése támogatni fogja a rövid kurzusokkal való képzést és a nyílt tudománnyal összefüggő készségeket a könyvtár- és információtudományi oktatásban. A thai kutatóegyetemeken a kutatási adatokról végzett vizsgálat ${ }^{11}$ azt mutatja, hogy az egyetemek könyvtárai és kutatási központjai szolgáltatják a szakdolgozatokat, disszertációkat, kutatási jelentéseket és cikkeket. Három országos intézmény végez kutatási adatokkal kapcsolatos szolgáltatást:

A Thai Library Integrated System (ThaiLIS); amelyet az Egyetemügyi Minisztérium és a Thai Könyvtári Integrált Rendszer Projekt müködtet, a kutatási adatbázis neve Thai Digital Collection (TDC).

\footnotetext{
9 NONTHACUMJANE, P. 2010.

10 SALADYANANT, T. 2014.

11 WIPAWIN, N. 2016.
} 
A Thai Nemzeti Kutatási Repozitórium (TNRR), amelyet a Nemzeti Kutatási Tanács (NRCT) fejleszt, és a Thaiföldi Kutatási Intézmények Hálózata (TRON), amelynek tagjai különböző intézmények közül kerülnek ki, ilyenek a Nemzeti Tudományos és Műszaki Fejlesztési Ügynökség (NSTDA), a Thaiföldi Kutatási Alap (TRF), a Nemzeti Tudományos, Müszaki és Innovációs Politikai Hivatal (STI), az Egészségügyi Rendszerek Kutatóintézete (HSRI) és a Mezőgazdasági Kutatási-Fejlesztési Ügynökség (ARDA), továbbá a Thai Journals Online (ThaiJO), amelynek a Thai Journal Citation Index Centre (TCI) ad helyet, ez a King Mongkut University of Technology, Thonburi részlege (olyan e-folyóiratrendszer, amely ötszáznál több thai folyóiratot tartalmaz).

Azt tapasztaltuk, hogy a legtöbb thai adatbázis tartalmaz kutatási eredményeket (kutatási beszámolókat és cikkeket). Mivel nincsenek intézményi eljárások a nyílt kutatási adatokkal kapcsolatban, ez az intézményekben a kutatásokkal és a disszertációkkal kapcsolatos adatok korlátozott hozzáféréséhez vezethet. A metaadatok és a tartós azonosítók szükségessége is befolyásolja az adatok hosszú távú megőrzését az adatbázisokban. A legtöbb thai egyetem szolgáltat teljes szövegü eletronikus szakdolgozatokat és disszertációkat a ThaiLIS, az OPAC, valamint az adatbázisok számára, és a legtöbb könyvtár átadja a szakdolgozatok fájljait a thai egyetemi könyvtári konzorcium, az Egyetemügyi Minisztérium és a Thai Könyvtári Integrált Rendszer projekt keretében a ThaiLIS adatbázisainak. A Thai Nemzeti Kutatási Repozitórium (TNRR) szintén ad linkeket kutatási összefoglalókhoz és jelentésekhez, hogy a felhasználók hozzáférhessenek az egyes adatbázisokhoz. Általánosságban véve az egyablakos szolgáltatásokat célzó együttmüködések előre viszik a szolgáltatásokat. Tehát a tudományos kommunikációs kompetenciák szerepeltetése a könyvtár- és információtudományi tantervekben támogatja a könyvtár- és információtudományi oktatást.

\section{Irodalom}

Association of Research Libraries (2016): Scholarly communication. Forrás: https://library.uwinnipeg. ca/scholarly-communication/index.html [2018. október 31.]

BAPORIKAR, N. (2017): Enhancing scholarly communication through research culture. Scholarly communication and the publish or perish pressures of academia. Chapter 5. Osmania University, India, 74-99. p. Forrás: https://doi.org/10.4018/978-1-5225-1697-2.ch005 [2018. október 31.]

BELZILE, S. [et al.] (2010): Core competencies for $21^{\text {st }}$ century CARL librarians. Canadian Association of Research Libraries. Forrás: http://www.carl-abrc.ca/strengthening-capacity/human-resource-management/core-competencies-21st-century-carl-librarians/ [2018. október 31.]

BRINEY, K. (2015): Data management for researchers. Organize, maintain and share your data for research success. Exeter, UK: Pelagic Publishing, 2015.

CALARCO, P. [et al.] (2016): Librarians' competencies profile for scholarly communication and open access. Joint task force on librarians competencies in support of e-research and scholarly communication. CARL (2010): Core competencies for $21^{\text {st }}$ century CARL librarians. Forrás: https://www.carl-abrc.ca/ doc/core_comp_profile-e.pdf [2018. október 31.] 
CROSS,W. [et al.] (2017): Jump start your scholarly communication initiatives. Lessons learned from redesigning the scholarly communications roadshow for a new generation of librarians.

Forrás: http://www.ala.org/acrl/sites/ala.org.acrl/files/content/conferences/confsandpreconfs/2017/ JumpStartYourScholarlyCommunicationInitiatives.pdf [2018. október 31.]

DHANAVANDAN, S. -TAMIZHCHELVAN, M. (2015): Institutional repositories in BRICS countries. A study. International Journal of Knowledge Content Development \& Technology, 5. 1. June 2015. 33-47. p. Forrás: https://doi.org/10.5865/IJKCT.2015.5.1.033 [2018. október 31.]

GBAJE, E. S. [et al.] (2018): Assessing the competencies and skills of academic librarians in Nigeria for scholarly communication. IFLA WLIC2018

MATUSIAK, K. K. (2014): Educating a new generation of library and information science professionals. A United States perspective. LIS Faculty Publication.

MATUSIAK, K. K. - SPOSITO, F. A. (2017): Types of research data management services: An international perspective. Forrás: https://onlinelibrary.wiley.com/doi/full/10.1002/pra2.2017.14505401144 [2018. október 31.]

MEARS, K. [et al.] (2017): Investigating the need for scholarly communications positions in Association of Academic Health Sciences Libraries member institutions = Research Communication, 105. 2 April. 2017. Forrás: http://jmia.mlanet.org; https://doi.org/10.5195/JMLA.2017.208 [2018. október 31.]

NONTHACUMJANE, P. (2010): Essential competencies of an information professional working in a digital library environment, in the opinions of Norwegian and Thai library and information science educators. Master thesis. International Master in Digital Library Learning.

O'CARROL, C. [et al.] (2017): Providing researchers with the skills and competencies they need to practise Open Science. Open Science Skills Working Group Report. Forrás: https://ec.europa.eu/research/openscience/pdf/os_skills_wgreport_final.pdf\#view=fit\&pagemode=none [2018. október31.]

ROEMER, R. C. - BORCHARDT, R. (2015): Meaningful metrics. A 21st-century librarian's guide to bibliometrics, altmetrics, and research impact. Chicago, The Association of College and Research Libraries. http://www.ala.org/acrl/sites/ala.org.acrl/files/content/publications/booksanddigitalresources/ digital/9780838987568_metrics_OA.pdf [2018. október 31.]

RUSSELL, R. - DAY, M. (2010): Institutional repository interaction with research users. A review of current practice. $=$ New Review of Academic Librarianship Forrás: https://www.tandfonline.com/doi/ abs/10.1080/13614533.2010.509996 [2018. október31.]

SALADYANANT, T. (2014): Library and information science curriculum in Thai universities compared with IFLA Guidelines for professional library/information educational programs. Available from: https://www.researchgate.net/publication/275544196_Library_and_Information_Science_Curriculum_in_Thai_Universities_Compared_with_IFLA_Guidelines_for_Professional_LibraryInformation_Educational_Programs https://doi.org/10.1016/j.sbspro.2014.07.127 [2018. október 31.]

SEMELER, A. R. [et al.] (2018): Data science in data librarianship. Core competencies of a data librarian. = Journal of Librarianship and Information Science Forrás: https://journals.sagepub.com/ doi/10.1177/0961000617742465 [2018. október31.]

WIPAWIN, N. (2016): Research Data Services in Thai Research Universities. Proceedings of ISS 2016 International Conference on Information and Social Science. 23-27 June 2016. Sapporo, Japan 
Namtip Wipawin egyetemi docens; $\mathrm{PhD}$ fokozatát az Egyesült Királyságban, a Loughborough-i Egyetemen szerezte könyvtár- és tájékoztatástudományi szakterületen. Jelenleg a Sukhothai Thammathirat Open University információtudományi PhD programjának az elnöke a Bölcsészettudományi Iskola Információtudományi Tanszékén. Korábban vezetői állásokat töltött be a Thai Kereskedelmi Kamara Egyetemének és a Sripatum Egyetem könyvtárigazgatójaként. A Thai Könyvtárosegyesület elnökségi tagja, ezen egyesület nemzetközi csoportjának vezetője (2004-2007 között, majd 2009-től napjainkig), tagja az Írástudás Nemzetközi Egyesületnek. Korábban tagja volt az IFLA Ázsia és Óceánia Szekciója (SC Asia and Oceania Section) állandó bizottságának (2005-2009), a Nemzetközi Olvasástársaság (International Reading Association) technológiai, kommunikációs és írástudással foglalkozó bizottságának (2010-2011), valamint elnöke volt a Thaiföldi Olvasástársaságnak (Thailand Reading Association, 2008-2010). 